\title{
God and the Sacredness of Art From the Perspective of Worship
}

\author{
Iacob Coman
}

\begin{abstract}
When talking about sacredness, in general, and about the sacredness of art, in particular, the problem of morality intervenes from a biblical perspective. This is because whenever we have to do with the artistic sacredness, we have to do with an election through which we switch from worshiping God to something else entirely. In the present research we will try to put the scientific-dogmatic basis on the issue of the above. Without claiming to solve the problem, we will emphasize, however, some nuances trying to take into account both the artistic vocation and the artistic intention, both the vocation of the artist and the artist's intention.

KEY WORDS: artistic sacredness, idolatry, artistic vocation, artistic purpose, holiness
\end{abstract}

\section{Introduction}

The sacredness, though always has a destination other than the common, does not always have a divine destination. There are objects and places, parts of literature and music that have become sacred due to their historical value, due to the author or because of the message they bear, but which are not intended to God. In this context we can talk about some monuments to the glory of heroes, or patriotic musical-artistic compositions etc., artistic events that are set aside, commemorated and that claim an attitude of sacredness 
from those bound emotionally and metaphysically to the moments evoked.

Complementarily, as artistic value and religious law, are those parts of the sacred art which are intended to a "reality", that people consider as transcending the perishable reality, and which lie somewhere outside time. This sacred art is intended either to the gods or to God. In this new orientation regarding the recipient of art, its sacredness becomes an object of controversy and authenticity, but never on the reality of its sacredness, but always on the addressee. Are searched arguments for or against the existence of the alleged deity. At this level, sacredness implies a different bond between the spiritual dimension of the human being and the sacredness of the art in question.

For many centuries, art and the artistic phenomenon were quite strictly related to the religious life of people. In other words, what was painted, carved, the most important musical events etc. were created for the gods. At the Phoenicians, for example, we talk about the famous Temple of Byblos. ${ }^{1}$ There remained some of the sacred artistic achievements of these people. If we were to talk about the Greeks, "from the beginning it should be noted that the Greek art, except the later ages, was inextricably linked to religion."2 The idea of art as freedom, through which one could get out of the bonds of religion, in general, and from the bonds of the Christian church, in particular, is very new and foreign to ancient times.

Art confirms that artistic freedom is only of those who were "bound" artistically through birth. To multiply, in schools, people who will be able to draw or compose does not assume in any case to multiply or to diminish the number of those who were given to be artists. "And the Lord spake unto Moses, saying, See, I have called by name Bezaleel the son of Uri, the son of Hur, of the tribe of Judah: And I have filled him with the spirit of God, in wisdom, and in understanding, and in knowledge, and in all manner of workmanship, to devise cunning works, to work in gold, and in silver, and in brass, and in cutting of stones, to set them, and in carving of timber, to work in all manner of workmanship." (Exodus 31: 2-5) Of those who were given the Spirit, none will ever be artless and of those who were not given the Spirit none will ever be artist. This is why sacred art and 
profane art can not be regarded as having different origins, but as having different destinations decided by those who got the freedom and the call of art from the same Providence, God.

In the present research, we will try to make observations about worship considering the sacredness of art and the existence of God. The artistic sacred inclination and the reverent bending toward God should never be confused. There must be a clear distinction between what man puts aside with artistic sacred destination and what puts God aside with sacred destination and which may have an artistic dimension. Rudolf Otto gives us some information about a "historical appearance of the category of the sacred"3 ${ }^{\prime 3}$ tarting from magic and reaching patriarch Jacob's reaction, who winces in the place where he had a dream and declares that there was God, that is the sacred, and he did not know. In Rudolf Otto there is not a clear distinction between God, as sacred, and the sanctity which He claims, on the one hand, and the sacredness of the religious artistic details, that are born from the religious artistic dimension of the artists. This, as we shall see in the following chapters, it is equally evident in music. We make confusion between Bach's sacred music and the sacred music that God requires. In the case of Bach, we are dealing with an artistic intent of the great composer. He creates music provided to the sacred environment. This music acquits itself brilliantly of the duty of corresponding to the sacred space and of suggesting the ideea of sacred, but it is a reality that proposes something to God, not a reality that responds to what God requires. The sacred music that God demands is the one we reproduce, not the one we compose for Him.

It is quite unlikely that in this short study to exhaust what we question, but our responsibility on discerning the idea of "Sacred Art" is more than necessary. This responsibility makes us more honest before God, and before ourselves and, at the same time, protects us from idolatry. The way man moved away from the sanctity of God is more important than how the sanctity that man created for God developed, the latter certainly not pleasing God. 


\section{A. The Sacred, Brief Historical Perspective}

From a chronological point of view, the idea of sacred or religious outruns the Hebrew people, but it does not outrun the God of the Holy Scriptures. The idea of sacred does not even outrun the antagonism between the sacred, as artistic mythological idea, and the sacred, as reality required and accepted by God. We find the first case of antagonism shortly after the expulsion from paradise when "the Lord had respect unto Abel and to his offering: But unto Cain and to his offering he had not respect." (Genesis 4: 4-5) In that case we see for the first time the difference between sacredness as obedience and sacredness as initiative, as creation. The first one is accepted by God, and the other is rejected. God is impressed negatively by the human initiative. From that time until today the sacred has only these two shades: the shade towards which God looks with pleasure, and the shade towards which God looks without pleasure. In terms of layman the above are less relevant, because at this level the sacred and the sacred art are regarded as synergistic realities that cover any artistic aesthetic intentionality, either religious or secular. From a Biblical perspective, and consequently in terms of God, things are different.

When we discuss this subject from a theological point of view, all the artistic reality included in the idea of sacred is reduced to two perspectives: the sacred artistic requested and pleasing to God (such as the ornaments from the Tabernacle and from the Temple of Solomon, and the furniture in the Tabernacle and from the Temple) and the sacred artistic refused by God (as all the sculptures and the paintings that fall under the second commandment: "Thou shalt not make unto thee any graven image, or any likeness of any thing that is in heaven above, or that is in the earth beneath, or that is in the water under the earth: Thou shalt not bow down thyself to them, nor serve them." (Exodus 20: 4-5). That is why the issue of art and of the artist is much more severe than is typically. The independence of the artist towards the community thinking is always counted as a virtue and as a breakthrough of all everything that is art, but the

artist's independence towards the requirements of God can be a 
rebellion. Switching the position from progress to rebellion is very easy, but very difficult to notice. That is why, from a theological point of view the appreciation or rejection of sacred art is very delicate and requires great responsibility.

Speaking chronologically, the sacredness before the existence of the Hebrew people is very evident. The feeling and the artistic achievement were in some pre-Hebrew civilizations identical to the place of worship, the sculptural or pictorial representation of gods and to the sacred object, meaning God or a higher imaginary being. Aurel Codoban notes that "in relation to the religious experience, sacred is considered for only a century. Until the nineteenth century, the interest is moving either to the existence and nature of God, or to the institutional role of religion." ${ }^{4}$ In these circumstances, the sacred was something that did not belong to man, it was a reality attributed only to the reality that bind the gods or to the place of worship. The sacred was alien to the human being and characteristic to the gods, but men lived their daily lives under the rule of the sacred.

Long before the Hebrew people, from Cain, and later by Hamand Japheth, the sons of Noah, branched off a parallel and antagonistic world to God's world. This world lays the foundation of certain civilizations that are counted as a holy dowry of mankind, and their culture and art are of another type of interest than the biblical culture and arts. In these cultures, that surpass the Hebrew one, art can not be separated from the idea of the sacred and the sacred manifestation. In the Hittite world, for example, art identifies itself with the architecture of the temple and the painting, with the sacred scenes. "The procession from the rupestral sanctuary from Yazili-Kaia is a real procession and not a sequence." In other words the art from there is in fact a "liturgy". This was no less evident in the Egyptians. In them the music was "holy art in the temples where the illusionists spelt the god, accompanying themselves with harp, from which came a whole sacerdotal orchestra in times of great eulogies." ${ }^{6}$ The existence of sacred art before the Hebrew people and the biblical culture is often used to suggest that, chronologically, the Bible art comes after the art of the great civilizations and, therefore, is tributary to them. As a theologian I can not agree with such an assumption. The artistic dimension of the tabernacle has nothing 
to do with the artistic dimension of other places of worship ${ }^{7}$ from other civilizations prior to theirs. The action took place in a place foreign to other civilizations, in the wilderness, and the model and the details were provided by God: "And look that thou make them after their pattern, which was shewed thee in the mount." (Exodus 25: 40) If we were to talk about similarities, they are unilateral, only from God to the human culture. The human intentions of the Jews to copy certain things from other peoples were severely fined by God.

When we talk about the biblical sacred art, we have the obligation to manage it differently. It is not of human origin, it was not the human artistic feeling that generated it. "And Moses said unto the children of Israel, See, the Lord hath called by name Bezaleel the son of Uri, the son of Hur, of the tribe of Judah; And he hath filled him with the spirit of God, in wisdom, in understanding, and in knowledge, and in all manner of workmanship." (Exodus 35: 30-31) In the biblical sacred art we have to do with the intentionality of God to do something beautiful, which is why someone is filled by the Spirit of God. The artistic dimension of the priestly garments and the artistic dimension of the tabernacle and the temple should be regarded as originating in God. "The inventor of colors, shape, texture, author of all natural beauties clearly appreciates the aesthetic dimension itself. According to the clear lines of the Scripture, art has its place within God." ${ }^{8}$ The aesthetic and artistic dimension of beauty, that does not fit within God, is a pseudo-art, although it has our endorsement as specialized people and as beauty-loving people. God always claimed its destruction: "Take heed to thyself, lest thou make a covenant with the inhabitants of the land whither thou goest, lest it be for a snare in the midst of thee: But ye shall destroy their altars, break their images, and cut down their groves." (Exodus 34: 12-13) These altars, these abominable pillars and these idols were works of art of great value from our point of view, but from God's perspective they were some things that needed utterly destroyed.

The same is true in music. Only the music that rests in God, only the music that praises God and worships God can be considered art, all other forms of music, no matter how brilliant they may be, will prove to be pseudo-harmonies or even idolatry. But also 
this music that rests in God must have the character of an answer, answer that God can assume as an act of His creation. Just as the Bible is not created by man for God, but God uses man to create His own revelation, so that the music we accept as sacred must be, in some way, the creative act of God. This is why the music from the Scriptures, and which was characteristic to a people, should be regarded as sacred music as a whole. "Bible intersects mainly with the sacred music. When it makes, although rarely, allusion to secular music, it is virulently criticized." 9

Distinct and distinguished, the Hebrew people leads, in the history of the Bible, a music that answers God's requirement. "The Jews did not know any other combination of music, than the one with religion." ${ }^{10}$ Their worship life, their daily life and their war life was a life impregnated with sacred chant. In this, God was always found. "Very close to the priests were the psalmists whose hymns and songs, supplications and praises were used by the priests officiating in the temple and in the gatherings of Israel, united in adoration." ${ }^{11}$ In the Scriptures everything that can be associated with the sacred art is associated implicitly with the requirements of God and the obedience to Him, and any other artistic achievement, regardless of its value is associated with other nations and disobedience to God. They had to be always destroyed.

The sacred music associated with the people of the Bible is as "old" as God. The Jewish Encyclopedia talks about Jubal as "the mythical father of music and he is considered to be the inventor of musical instruments." ${ }^{2}$ "And his brother's name was Jubal: he was the father of all such as handle the harp and organ." (Genesis 4, 21) The Hebrew people did not come into being in the line of Jubal, but the line of Seth, which is why we think that what will happen in the Jewish people can be different. However we note that the music is very old and we want to say that, in the history of music, it was firstly an involution in the music from Eden, a rupture due to forgetfulness and inconsistency in education. Then, perhaps, there was the evolution we're talking about in the treaties of music history. Returning to the Hebrew people we will notice that their artistic musical enthusiasm is very evident. "The Jews, writes Christian Friedrich Daniel Schubart, surpassed other nations. They gave 
very early great masters both in vocal music, and the instrumental, masters they called menatzeachs, and whom we call in our language virtuosos."13 We see thus that the Jewish sacred music was vocalinstrumental, "noisy", accompanied by shouts of joy. In the Scriptures we find marked manifestations of this kind and find requests to manifestations of this kind: "Make a joyful noise unto the Lord, all the earth: make a loud noise, and rejoice, and sing praise. Sing unto the Lord with the harp; with the harp, and the voice of a psalm. With trumpets and sound of cornet make a joyful noise before the Lord, the King." (Psalms 98: 4-6)

The Christian era begins quite differently in terms of sacred music. The social context in which the Gospel was to be preached was one clearly shaped around something sacred and secular. The Greek Theatre which made its debut "as a choral piece sung by a choir singing the glory of god Dionysus" 14 and which had a religious character had been secularized. Had also appeared the secular theaters, ambulant street theaters which promoted a fashionable life. Saint John Chrysostom harshly criticized these artistic manifestations stating that their attendance blocks the interest for the Scriptures and church: "It is seen that from what you collect when you return home from the theater. Each of you brings home the whole mire of words and songs of laughter, bestowed there upon you. But, better said, you not only bring it home, but each of you puts it in his soul." ${ }^{15}$ Music and dramatic arts, instrumentation and artistic behavior promoted a jovial life. The religious element does not exist in these demonstrations. The religious art began to be more specific remaining characteristic only for the temples or on occasions of purely religious events.

In this new context, the instrumental music was associated with the laic manifestation, with the theater scenes, which is why it will not be promoted in Christian worship services. Badea Cireşeanu, ${ }^{16}$ in his work Liturgical Thesaurus, shows the reluctance to the instrumental music in the early church, showing that the lack of church decisions on this issue is because "Instrumental music was introduced in the Latin Church after the patristic and ecumenical councils age." ${ }^{17}$ Some of the church fathers speak very negatively about the opportunity to praise God in church with 
musical instruments. “. . Trumpets, flutes, plays, their subjects, in a word, all are full of the biggest debauchery." ${ }^{18}$ This mode of worship remained outlawed until today, at least in the Eastern Church. In the Western Church, although since the eighteenth century the orchestra was admitted, there are some situations where instrumental music is clearly prohibited: "In the Sistine Chapel and in any church where the pope would officiate, in the churches of Lion and in any Latin Church during Great Lent."19

In conclusion, we are seeing clearly that, in terms of sacred music, there are big differences when we talk about the proposal of the religious communities regarding what music is sacred an what is not. The opinion remains constant only when it comes to the text of the Scripture. In other words, the sacred is not about what we offer, but what we are asked by God. "... To obey is better than sacrifice, and to hearken than the fat of rams." (I Samuel 15: 22) That is sacred art is related to the obedience to God, the art proposed to be sacred is related to the artistic re-designed that is made by man, but has no value before God.

\section{B. Sacredness as Artistic Destination}

When considering the sacredness of objects and places, we consider a particular dimension of the human capacity to create. In the human artistic creation we find, in the fullest mode of expression, the dimension of the Divinity. This dimension does not refer to shape or color, harmony or rhythm of the identity that can be found in image or sound, but this dimension has to do with the strength to do something aesthetic, a power characteristic, as we said, to the Divinity, characteristic that was also given to us, through what the Bible calls the "image and likeness": "And God said, Let us make man in our image, after our likeness: and let them have dominion over the fish of the sea, and over the fowl of the air, and over the cattle, and over all the earth, and over every creeping thing that creepeth upon the earth. So God created man in his own image, in the image of God created he him; male and female created he them." (Genesis 
1: 26-27) So, man can create something with a certain sanctity in itself, and this argument is found only in art.

Sacredness, in the development of the community and human history, represented the time and place where art had its destination. Everything was addressed to the real divinity or the imagined divinity. For the Greeks, "music was one of the elements of worship and few religious ceremonies were held without songs." ${ }^{20}$ In other words, the act of artistic creation was intended for the religious ceremony. The composer created for the divinity and the creative act itself was intended for that divinity. In this situation, the musical composition considered, strictly, a cultic setting and an atmosphere of sacredness. "The Romans associated music with the divine service since the days of Romulus, but especially under Tullus Hostilius" 21 and "the Sumerians, as the ancient Egyptians, gave music an important place in the worship of the gods....22 In these circumstances, we see that the novelty of the compositional space, as well as the consumption of musical art was determined by "the presence of the gods". People and artists felt that the only place where they needed to apply the creative act had to be a sacred place.

Another example is the Egyptian art. It is full of superstitions, spells, with a deeply religious content. "Egyptian art did not have beauty as summum bonum (supreme good), it was not an art for art, but an art employed, aiming at specific purposes, and in no case aesthetic; just as an orthodox icon does not want to achieve beautiful and beauty, these being secondary and adjacent aims." ${ }^{23}$ We deduce from those specified by Constantin Daniel, that, at origins, engaging in artistic creation, whether it be music, whether it be painting or sculpture, was an employment related to sacredness. Artistic destination was not the beauty, but the sacredness. The beauty of art was the effect and the supporting element of the creation itself. Under these conditions the artistic achievement was consecrated by the purpose, not by the aesthetic, and the goal was always a religious one, that is sacred.

To be noted is the fact that in contemporary lay art there are not so many things changed. The time and the space for which are intended the paintings, the sculptural and the musical works have a certain sacredness. The exhibition hall, the concert hall gives us the 
time and space where we load ourselves with a particular sacredness. Even at home, to the works of art we give some sacred space and an attitude of sacredness. The sacredness may be foreign of God, but it is real. The contemporary painter, the contemporary composer, the contemporary sculptor, that is all those ordained through birth to an artistic inclination, lie in their creative act in a particular "seizure" of sacredness. This makes them different and, at the same time, free. The common denominator between the human being and the Divine Being, as we noted above, remains the creative artistic act. God's passion for what is artistic and with sacred valences is unequaled and the artist encounters God in exactly this dimension he got, through creation, from Him. We talk in this manner about the most complex denominator between the uncreated God and the created human being. The common denominator, "the artistic craftsmanship", makes that all human artistic creation be a response to God's creation, a replica in which is found in entirely other dimensions the artistic purpose and the artistic purpose, meaning the sacred.

\section{The Sacred of Sanctification as Worship and as an Idolatrous Element}

When we talk about sacredness in terms of sanctification, things change radically. In other words, any sacrality should contribute to our sanctification. The sacred artistic which does not sanctify us, secularizes us or becomes idolatry. No matter how largely we uploaded semantically the term sacred, the idea itself is either favored by God, implying the holiness of those bound by that sacred, or rejected by God, implying the secularization of the person related to these or his bending to idolatry. From the perspective of the biblical theology it is quite difficult, if not impossible, to speak of a neutral sacrality. "For the religious belief, however, the sacred is a real manifestation of the Divine Being and a testimony of the divine existence. It intervenes in the religious experience, as a set of signs through which the divinity communicates with people and people can get in touch with the Divinity...."24 The sacred objects and sacred music, if they are created by God through us, bring us closer to Him 
and sanctify us, but if they are created by us both as initiative and as achievement, the situation becomes unsafe. When building the Temple by Solomon all the details of the artistic sacredness were specified by God, so that Solomon's Temple was not only a place for sacred behavior, it was a place where through the atmosphere itself man was sacralized, i.e. holy. "David gave his son Solomon ... everything he had in mind for the courts of the House of God and of all the chambers all around, of the treasuries of the House of God and the treasures of the Sanctuary.... He gave him the image of the tools of gold, with the weight for those which were supposed to be of gold, for all instruments of every kind of service; the image of the tools of silver, with the weight for those which were supposed to be of silver, for all instruments of every kind of service. He gave the weight of the golden candlesticks and their lamps of gold, with the weight for every candlestick and lamp; and the weight of the silver candlesticks, with the weight for every candlestick and lamp, for the usage of every candlestick ... and the altar of incense from refined gold by its weight. He also gave him the image of the gold chariot of cherubim that spread their wings and cover the ark of the covenant of the Lord. "All this, said David, the Lord made me understand in writing by his hand upon me, even all the works of this pattern." (I Chronicles 28: 11-19) From this description we easily deduce how thoroughly is God on every detail of the sacred art. We are talking about a condition where the artistic element is performed by God through man-artist. This reality, that can be taken as a paradigm in our research, suggests and explains the difference between the supply of sacred art, as human initiative, and the answer to create sacred art, as a requirement from God.

The situation doesn't change too much when talking about the musical artitic sacred. Building up the melody, the harmony, the rhythm, the atmosphere of praise must occur within the same paradigm. The sacred music must be an action of God in the composer, a comprehensive and detailed action. Providing, as a composer, a composition as a sacrifice to God is an act of great artistic nobility, but being, as a composer, a vessel in which God puts his heavenly harmonies, is a great gesture of obedience and repentance. Here's how the psalmist notes that: "I waited patiently for the Lord; 
and he inclined unto me, and heard my cry. He brought me up also out of an horrible pit, out of the miry clay, and set my feet upon a rock, and established my goings. And he hath put a new song in my mouth, even praise unto our God: many shall see it, and fear, and shall trust in the Lord." (Psalms 40: 1-3) The sacred music must be an intentional action of God, action that occurs in the ineffable of the one who conceives it, bears it and puts it in front of God as something that belongs exclusively to God.

Secondly, when we talk about the sacredness of sanctification we should keep in mind the fundamental element of the relationship between man and God, that is worship. The conventional language or the artistic language allows us expressions like: "dedicated to the heroes", "dedicated to the famous Brâncuși", "dedicated to the brilliant Bach", "dedicated to homeland," etc., but reality itself is more severe: what is not given to God is idolatry, no matter whom it would be dedicated to.

The issue of these thesis obliges and empowers us. Which is the sacred art that sanctifies us on the text line of the Bible? Which is the sacred music that sanctifies us on the text line of the Bible? Here we do not have in mind the wellness given to us by the artistic admiration, or the inner peace given to us by listening to classical music, here we will consider how the sacred artistic image or the sacred artistic harmony repairs or destroys the relationship between us and God, through the teachings of the Bible. Any reality that compromises the process of sanctification becomes a serious wall between us and God. This wall can prevent the encounter with God and prevent our seeing of God. The sacred requires the divine reality that surrounds us through the baptism of re-birth, and which enables us to see God in a spiritual way. Here is what Nichifor Crainic notes: "Not from hearsay or taught is known God, but from seeing Him. How can you talk to someone without seeing him? How can you pray to Christ without seeing Him?" 25 The artist, the composer, the interpreter need to seek the area where God will be able to influence them. Their work should enable us to sanctify ourselves and to approach God. "Scripture teaches us that when it sanctifies us, God renews us into His likeness, making us more like Christ." ${ }^{26}$ 
In other words, sacred art should have the power to deify not to secularize us, to spiritualize us not to humanize us.

In the third place, we reformulate the above questions: which is the sacred art that helps us worship God on the biblical text line? Which is the sacred harmony that helps us worship God on the biblical text line? Bach's sacred music is neither more nor less sacred than a simple Romanian doina in which the peasant tears his hearts before God. If from the harmonic point of view and in terms of compositional rigor rules, Bach's harmonies express the professional quality of a high level brilliant composer, and doina or the mourning of a peasant, in terms of the same evaluation criteria, expresses the un-scholastic commonplace of a musically uneducated, then, from the point of view of the relationship with God, there is no difference between these two creations. What makes them different or what makes them similar in terms of the relationship with God is the divine element through which we worship God properly. The music I sing should be my worship, a doxological worship. My mind exposed to praise and worship and, at the same time, praising and worshiping, must appear as being in the complete and complex presence of the Godhead. "When we reflect on the Father as boundless, the uncreated, we reflect also on the Son and the Holy Spirit, for the Son and the Holy Spirit can not be outside this comprehensive infinity and beyond their own living outside its uncreated glory, wisdom and omnipotence, "but it is contemplated in each the unbroken and undivided common"."' ${ }^{27}$ In these circumstances the sacredness of musical art should be seen as a response to God's initiative, response in which are reflected both the praise and worship and our sanctification. Also, this complex of sacred art should be doxological.

In conclusion, when we talk about the sanctity of art and its evaluation we need to consider not only the human religious feeling, but the complex authority of the Bible from which we learn what is sacred and what is pseudo-sacred. The inner human sacredness can propose to the artistic phenomenon and the artistic achievement their value in terms of price and artistic creations, elements that can sometimes be confused with sacredness, but in reality the artistic phenomenon is sacred only if it is an unaltered response to what 
God requires. Art is sacred only if God feels comfortable in it, unless it completes His presence and His holiness. "And when Moses was gone into the tabernacle of the congregation to speak with him, then he heard the voice of one speaking unto him from off the mercy seat that was upon the ark of testimony, from between the two cherubims: and he spake unto him." (Numbers 7: 89) The Ark as artistic achievement was not in any way inconsistent with "the philosophy" of God and it was not in any way inconsistent with the presence of God. Analogically speaking, the artistic sanctity bears the mark of authenticity only when it is not in disagreement with the Bible and only when it is absorbed into the presence of God.

Such an artistic context is one that turns the artistic amazement into spiritual amazement. The difference is radical. The artistic amazement claims the recognition of the artist's genius ability, the artistic amazement involves challenging in competition for those in the field, the artistic amazement claims the desire to become the owner of that work, etc. In contrast, the spiritual amazement claims you become the property of the divine, the spiritual amazement involves worship, prostration. The spiritual amazement implies to recognize an authority that can never enter into competition with anything human, but it is something from the personality and divine person that finds the indwelling in an artistic creation which, through its presence, sanctifies.

In these circumstances the sacredness of music should find, in the artistic tortuosity, the path through which God can be lowered into it. Such music and such composers can meet God desired frame, and, therefore, the framework sought by the ineffable human soul, eager for sacredness, holiness and living near to God.

NOTES:

1 Constantin Daniel, Civilizația feniciană (Phoenician Civilization), (Bucharest: Sport Turism Publishing, 1979), 196

${ }^{2}$ Enciclopedia civilizației grecești (The Greek Civilization Encyclopedia), translated into Romanian by Ioana and Sorin Stati, (Bucharest: Meridiane Publishing, 1970), 79. 
${ }^{3}$ Rudolf Otto, Sacrul (The Idea of the Holy), translated into Romanian by Ion Milea, (Cluj-Napoca: Dacia Publishing, 1996), 134-46.

${ }^{4}$ Aurel Codoban, Sacru şi ontofanie (Sacred and Ontophany), (Iași: Polirom Publishing, 1998), 49.

${ }^{5}$ Margarete Reimschneider, Lumea hitiților (The Hittite World), translated into Romanian by Paul B. Marian, (Bucharest: Științifică Publishing, 1967), 124.

${ }^{6}$ Georges Posener, Enciclopedia civilizației şi artei egiptene (Encyclopedia of Egyptian Civilization and Art), translated into Romanian by Radu Florescu and Gloria Ceacalopol, (Bucharest: Meridiane Publishing, 1974),196.

${ }^{7}$ Most commentators of the Old Testament try to impose similarities between the shape of the Hebrew place of worship and the place of worship af the other nations of that time. With consideration towards any scientific contribution we must specify that what was done for God at architectural level, and beyond, was received directly from God: "All this, said David, the Lord made me understand in writing by his hand upon me, even all the works of this pattern." (I Chronicles 28: 19).

${ }^{8}$ Gene Edward Veith, Jr., Starea artelor (Status of Arts), translated into Romanian by Agnes Dragomir, (Oradea: Cartea Creștină Publishing, 2000), 131.

9 Cf. Dicționar enciclopedic de iudaism (Encyclopedic Dictionary of Judaism), translated into Romanian by Viviane Prager, C. Litman, Țicu Goldstein, (Bucharest: Hasefer Publishing, 2000), 551.

${ }^{10}$ Christian Friedrich Daniel Schubart, $O$ istorie a muzicii universale (A History of Universal Music), translated into Romanian by Philomena Oşanu, (Bucharest: Muzicală Publishing, 1983), 46.

11 Isidor Epstein, Iudaismul (Judaism), Traducere de Țicu Goldstein, (Bucharest:Editura Hasefer, 2001), 80.

12 Cf. Dicționar enciclopedic de iudaism (Encyclopedic Dictionary of Judaism), translated into Romanian by Viviane Prager, C. Litman, Țicu Goldstein, (Bucharest: Hasefer Publishing, 2000), 551.

${ }^{13}$ Christian Friedrich Daniel Schubart, $O$ istorie a muzicii universale ( $A$ History of Universal Music), translated into Romanian by Philomena Oşanu, (Bucharest: Muzicală Publishing, 1983), 45.

${ }^{14}$ Cf. Enciclopedia civilizației grecești (Greek Civilization Encyclopedia), translated into Romanian by Ioana and Sorin Stati, (Bucharest: Meridiane Publishing, 1970), 540.

${ }^{15}$ St. John Chrysostom, Scrieri partea a treia (Writings, $3^{\text {rd }}$ part, translated into Romanian by D. Fecioru, (Bucharest: Publishing House of the Bible and Mission Institute of the Romanian Orthodox Church, 1994), 461.

${ }^{16}$ Badea Cireșeanu, Tezaurul liturgic al sfintei biserici ortodoxe de răsărit (Liturgical Treasure of the Holy Eastern Orthodox Church), $2^{\text {nd }}$ volume, 520-24.

${ }^{17}$ Badea Cireșeanu, Tezaurul liturgic al sfintei biserici ortodoxe de răsărit (Liturgical Treasure of the Holy Eastern Orthodox Church), $2^{\text {nd }}$ volume, 521.

${ }^{18}$ St. John Chrysostom, Scrieri, partea a treia (Writings, $3^{\text {rd }}$ part), translated into Romanian by D. Fecioru, (Bucharest: Publishing House of the Bible and 
Mission Institute of the Romanian Orthodox Church, 1994), 462.

${ }^{19}$ Badea Cireşeanu, Tezaurul liturgic al sfintei biserici ortodoxe de răsărit (Liturgical Treasure of the Holy Eastern Orthodox Church), $2^{\text {nd }}$ volume, 523.

${ }^{20}$ Cf. Enciclopedia civilizației grecești (Greek Civilization Encyclopedia), translated into Romanian by Ioana and Sorin Stati, (Bucharest: Meridiane Publishing, 1970), 370.

${ }^{21}$ Christian Friedrich Daniel Schubart, $O$ istorie a muzicii universale $(A$ History of Universal Music), translated into Romanian by Philomena Oşanu, (Bucharest: Muzicală Publishing, 1983), 65

${ }^{22}$ Rodica Oana Pop, Prelegeri de istoria muzicii universale - de la origini până la epoca barocului, Vol. I, (Lectures on the History of Universal Music - from Its Origins to the Baroque, $1^{\text {st }}$ volume), (Cluj-Napoca: Publishing House of "G. Dima" Conservatory, 1984), 20.

${ }^{23}$ Constantin Daniel, Civilizația Egiptului Antic (Ancient Egypt Civilization), 305 p., (Bucharest: Sport Turism Publishing, 1976), 272.

${ }^{24}$ Aurel Codoban, Sacru şi ontofanie (Sacred and Ontophany), (Iași: Polirom Publishing, 1998), 51.

25 Nichifor Crainic, Sfințenia împlinirea umanului (Holiness, Human Fulfillment), 124 p., (Iași: Publishing House of Metropolitan of Moldovia and Bukovina, 1993), 179.

${ }^{26}$ Melvin E. Dieter, Anthoni A. Hoekema..., Cinci concepții despre sfințire (Five Conceptions on Holiness), translated into Romanian by Florin Mermeze, (Oradea: Cartea Creștină Publishing, 1999), 69.

${ }^{27}$ Dumitru Stăniloae, Sfânta Treime sau la început a fost iubirea (Holy Trinity or in the Beginning Was Love), (Bucharest: Publishing House of the Bible and Mission Institute of the Romanian Orthodox Church, 1993).

\section{BIBLIOGRAPHY:}

Enciclopedia civilizației grecești (Greek Civilization Encyclopedia), translated into Romanian by Ioana şi Sorin Stati. Bucharest: Meridiane Publishing, 1970.

Dicționar enciclopedic de iudaism (Encyclopedic Dictionary of Judaism), translated into Romanian by Viviane Prager, C. Litman, Țicu Goldstein. Bucharest: Hasefer Publishing, 2000.

Cireșeanu, Badea. Tezaurul liturgic al sfintei biserici ortodoxe de răsărit (Liturgical Treasure of the Holy Eastern Orthodox Church). Bucharest, 1910.

Codoban, Aurel. Sacru şi ontofanie (Sacred and Ontophany). Iași: Polirom Publishing, 1998.

Crainic, Nichifor. Sfințenia, împlinirea umanului (Holiness, Human Fulfillment). Iași: Publishing House of Metropolitan of Moldavia and Bukovina, 1993. 
Daniel, Constantin. Civilizația feniciană (Phoenician Civilization). Bucharest: Sport Turism Publishing, 1979.

Daniel, Constantin. Civilizația Egiptului antic (Ancient Egypt Civilization). Bucharest: Sport Turism Publishing, 1976.

Dieter, E. Melvin, Hoekema, A. Anthoni ... Cinci concepții despre sfințire (Five Conceptions on Holiness), translated into Romanian by Florin Mermeze. Oradea: Cartea Creştină Publishing, 1999.

Stăniloae, Dumitru. Sfânta Treime sau la început a fost iubirea (Holy Trinity or in the Beginning Was Love). Bucharest: Publishing House of the Bible and Mission Institute of the Romanian Orthodox Church, 1993.

Epstein, Isidor. Iudaismul (Judaism), translated into Romanian by Țicu Goldstein. Bucharest: Hasefer Publishing, 2001.

Ioan Gură de Aur Sfântul. Scrieri, partea a treia (Writings, $3^{\text {rd }}$ part), translated into Romanian by D. Fecioru. Bucharest: Publishing House of the Bible and Mission Institute of the Romanian Orthodox Church, 1994.

Otto, Rudolf. Sacrul (The Idea of the Holy), translated into Romanian by Ion Milea. Cluj-Napoca: Dacia Publishing, 1996.

Pop, Rodica Oana. Prelegeri de istoria muzicii universale. - de la origini până la epoca barocului (Lectures on the History of Universal Music - from Its Origins to the Baroque), $1^{\text {st }}$ volume. Cluj-Napoca: Publishing House of "G. Dima" Conservatory, 1984.

Posener, Georges, Enciclopedia civilizației și artei egiptene (Encyclopedia of Egyptian Civilization and Art), translated into Romanian by Radu Florescu and Gloria Ceacalopol. Bucharest: Meridiane Publishing, 1974.

Schubart, Christian Friedrich Daniel. O istorie a muzicii universale (A History of Universal Music), translated into Romanian by Philomena Oşanu. Bucharest: Muzicală Publishing, 1983.

Veith, Gene Edward, Jr. Starea artelor (Status of Arts), translated into Romanian by Agnes Dragomir. Oradea: Cartea Creștină Publishing, 2000. 